\title{
Revolutionen og idrætten i Rusland
}

\section{Af_Søren Damkjoer}

Den Russiske Kommitte for Fysisk Kultur er det regeringsorgan. der i fremtiden skal organisere det russiske idrætsliv. Den Russiske Kommite er flyttet til det forfaldne Razumovskij-Palæ tæt ved metrostationen Kurskaja. Dette palæ blev beslaglagt af kommunisterne efter 1917, og blev benyttet til det første Sovetiske Institut for Fysisk Kultur. Her har Niels Bukh haft sin opvisning i Moskva i 1931. I 1972 flyttede Det Statslige Centrale Lenininstitut for Fysisk Kultur til nye bygninger i udkanten af Moskva ved metrostationen Cherkizovskaja. Bygningerne forfaldt, men var hovedsæde for de mest prestigefyldte forskningsinstitutter for idrætten. Inden den nye Russiske Kommitte flyttede ind blev der gennemført et gasningsprojekt, hvor tusindvis af rotter blev ombragt. Da centralvarmeanlægget blev sat igang, bredte der sig en stank fra de tusindvis af døde rotter i hele komplekset. En revolution, også en revolution i idrætslivet i Rusland, består i hovedrengøring, flytning og flytterod. Under gulvet af de traditionsrige bygninger ligger fortidens lig. Fra disse bygninger og disse organer skal fornyelse af det Russiske idrætsliv komme.

I august 1991 forsøgte en klike af generaler et kup mod Gorbachev, medens han selv var på ferie på Krim. Boris Jelzin, støttet af 50.000 demonstranter, krydsede kupmagernes planer.

Det blev indledningen til opløsningen af Sovjetunionen, og det blev indledningen til en opløsning af det sovjetiske sportssystem, den Store Røde Maskine. Under Gorbachevs slagord fra 1985 om Omstrukturering, Åbenhed og Demokratisering havde det sovjetiske sportssystem været afficeret af de samfundsændringer, der blev indledt med Gorbachevs reformprogam. Men det var både for sportens og andre samfundssystemers vedkommende kun et program. Programmet varslede ændringer inden for den bestående Partistats rammer, men de reelle ændringer skyldtes ikke programmet som sådan, men de utilsigtede revolutionære ændringer, som programmet medførte.

For idrættens vedkommende betød disse ændringer op til 1990 flere ting. Den Store Sport, som er den russiske populære betegnelse for eliteidrætten, blev ganske vist udsat for en stigende kritik, men flertallet af den sportens nomenklatura, der befolkede Goskomsport, uddannelsesinstitutionerne og forskningen, var besluttet på en fortsættelse med modifikationer. Nomenklaturaen er betegnelsen for den politiske udnævnelse til alle ledende poster i den sovjetiske samfundssystem. Enkelte yngre forskere krævede allerede på det tidspunkt, at hykleriet omkring den sovjetiske professionalisme blev smidt over bord. De krævede en regelret professionalisme på markedsbetingelser. I elitesporten gjorde der sig nu centrifugale tendenser gældende. Goskomsport, der reelt fungerede som et sportsministerium, krævede større uafhængighed af 
staten og af kommunistpartiet. Specialforbundene krævede ligeledes større uafhængighed af Goskomsport. Trænerne ytrede - åbenlyst deres utilfredshed med løn og arbejdsbetingelser, og de første trænere og atleter udnyttede de nye muligheder for et job i udlandet. De aktive atleter i nogle idrætsgrene gjorde oprør. De første atleter i ishockey, basketball og fodbold fik kontrakter i USA og Vesteuropa.

\section{Krisen}

Den $\varnothing$ konomiske krise accellerede i 199091. Inflationen steg. Der var varemangel og tomme butikker. Krisen ramte også elitesporten. Børne- og ungdomssportskoler fik $\varnothing$ konomiske problemer. Goskomsport havde dårligt råd til at sende hold til internationale turneringer på grund af knapheden på hård valuta. Den $\varnothing$ konomiske og sociale krise førte til et hidtil uhørt fænomen: Elitesporten mistede sin prestige. Partistatens prestigeobjekt, elitesporten, kom i vanskeligheder. Det blev svært at skaffe de helt basale fødemidler til den elite, der hidtil havde betragtet kaviar som et nødvendigt fødemiddel til restitution. Elitesporten blev suget ned i den økonomiske og sociale krise, der aftegnede sig i 1990.

Den sovjetiske massesport, som den blev kaldt, viste sig nu at være ikke-eksisterende. Hidtil havde forfalskede statistikker og indberetninger fra sportsdage og sportsfestivaller skabt en Potemkin-kulisse, der viste at omkring 60 millioner af sovjetborgere regelmæssigt deltog i breddesport og Fysisk Kultur. Men en række unders $\varnothing$ gelser i slutningen af 80.erne punkterede myten. Det var eet resultat af Glasnost. Det viste sig nu, at måske højst 5 til $6 \%$ af den voksne befolkning regelmæssigt var aktive i idrætsaktiviteter. Åbenbart havde den Sovjetiske model for sport som en del af den
Kommunistiske livsmåde spillet fallit. Den $\emptyset$ konomiske og sociale krise forstærkede de nedadgående tendenser. Der krævedes ikke den store idrætssociologiske ekspertise til at lokalisere årsagerne. Forværringen af de sociale vilkår for størstedelen af befolkningen gjorde deltagelse i idræt til en by i Rusland. Den i forvejen katastrofale situation blev værre. Nu blev denne miserable situation i offentligheden koplet sammen med den miserable sundhedstilstand i befolkningen som helhed og i dens enkelte grupper. Den faldende gennemsnitslevetid og sundhedsproblemer hos børn på grund af ensidig ernæring og miljøfaktorer skabte en panisk situation.

Sociologiske undersøgelser af ungdommens idræts- og kulturforbrug demonstrerede, at den generation, der var vokset op i 80.erne, var tabt for idrætten. Den unge generation tog tilflugt til en småromantisk ungdomskultur, der var lysår fra de officielle paroler. Den lille minoritet af den uofficielle kultur havde i nogle tilfælde intresseret sig for japansk kampkunst eller yoga. Men disse aktiviteter havde været forbudt eller som et minimum ildeset af Komsomol og partiet. Den uofficielle kultur stod for de kulturaktiviteter, der ikke var godkendt af kommunistpartiet. Partistaten havde mistet forbindelsen til den nye generation, også i forhold til idrætspolitikken. I storbyerne Moskva og Leningrad bredte der sig i den mandlige ungdom en muskel- og steroidkultur, der var uden for myndighedernes kontrol.

\section{Sammenligning med Vesten og Japan}

Gorbachevs åbenhedspolitik havde ført til, at sammenligninger ved vesten ikke længere var tabu eller kun havde til formål at demonstrere sovjetunionens overlegenhed. 
En ny model for sammenligninger viste sig, nemlig sammenligningen med den »civiliserede« verden. Den civiliserede verden var_Vesten og Japan. Disse sammenligninger, der var udbredt $\mathrm{i}$ den reformvenlige intelligentsia, var et kritisk redskab for reformtænkning. Sammenligningen med den civiliserede verden blev fremført på alle områder. For idrættens vedkommende førte dette til opdagelse af de handicappede. Der havde været enkelte klubber for handicapidræt, men det var en dråbe i havet. Ved de Olympiske Lege i Moskva i 1980 måtte Sovjetunionen afstå fra at arrangere de $\mathrm{Pa}$ raolympiske Lege, fordi Sovjet ikke selv havde en elite, og fordi et sovjetisk arrangement ville have afsløret det næsten totale fravær af en moderne politik for handicappede, også på idrætsområdet. Nu blev der fra flere hold efterlyst et program for idræt for handicappede. Når Sovjetunionen hidtil ikke havde haft en handicapidræt, skyldtes det en dybtliggende kulturel forestilling hos ledere, politikere og forskere om, at handicappede ikke kunne udvikle sig, så at alle tiltag derfor var spild af resourcer. $\mathrm{Nu}$ da eliteidrætten, der havde krævet broderparten af alle resourcer, ikke længere var så atttraktiv, så både forskere og trænere en mulighed i dette forsømte område. Disse opportunistiske aspekter var koplet med en oprigtig humanisme, der skulle vise sig at være det eneste grundlag, der kunne holde.

De nationale idrætter, der havde rod i de talrige folkeslag og nationaliteter, havde $\mathrm{i}$ hele Sovjetunionens historie spillet en sekundær rolle i forhold til de oplympiske idrætter. Den kommunistiske formel for den kulturelle nationalitetspolitik havde været »socialistisk i indhold og national i form «. Denne leninske floskel havde betydet, at de nationale og regionale mindretals idrætskultur, var blevet tilsidesat. Folkemord og folkeflytninger af hundredetusindvis af mindretallenes befolkninger have været hovedårsager til, at nationale idrætter og lege var uddøde. Disse leges snævre forbindelser med nationale og religiøse helligdage og festdage havde også gjort dem suspekte for Kommunistpartiets sports- og kulturpolitik. Men igennem hele Sovjetperioden var der etnografer og sociologer, der havde forsøgt at beskrive og optegne dem, og der var gentagne forsøg på at påpege, at de også havde en rolle at spille i den sovjetiske mulitnationale kultur. I løbet af 80.erne var der flere røster, der fremhævede disse leges betydning.

\section{Nytaenkning}

I Sovjetunionen gjorde der sig, trods- Kommunistpartiets magt- og meningsmonopol, et behov for en praktisk og ideologisk fornyelse af sporten og idrætten gældende. I midten af 80.erne blev der i selve de centralstyrede forskningsplaner krævet en gennemtænkning af det filosofiske og sociologiske grundlag for sporten og den fysiske kultur. Denne omstrukturering og omtænkning var utvivlsomt grundlagt længere tilbage. På dette punkt er der en slående kontrast til DDRs sportsfilosoffer og sociologer, der først opdagede forandringens nødvendighed, da muren var faldet. Dette centralstyrede initiativ førte til en betoning $i$ avangardekredse af den fysiske kultur som en del af den almene kultur og af individets kultur. Her lå kimen til den fremhævning af det individuelle og af en humanistisk idrætsfilosofi.

\section{Opløsning}

Sovjetunionen blev opløst i december 1991. Allerede i August og september var de baltiske republikker udtrådt af Unionen og var blevet anerkendt som selvstændige stater. 
For elitesporten var disse måneder præget af en stigende panik. Elitesportens nomenklatura og Goskomsport klyngede sig til -den ide, at elitesporten kunne holdes sammen også i den fremtidige statsmodel for eks-sovjetunionen. Men med udgangen af 1991 forsvandt Unionen, og derved Goskomsport og den sovjettiske sportsorganiation. Forude i 1992 stod de Olympiske lege i Albertville og i Barcelona. Verdens sportstormagt nummer eet var brudt sammen ved optagten til det Olympiske år 1992.

Efter hektiske forhandlinger med IOC blev det besluttet, at de 11 stater i SNG skulle udgøre et såkaldt forenet hold ved vinterog sommerlegene i 1992. De 3 baltiske lande stillede allerede op med selvstændige hold. Georgien, der ikke var medlem af SNG, deltog også på det forenede hold, meget mod sin vilje. Denne løsning blev gennemtvunget af Samaranch og formentlig også af hovedsponsoren for det forenende hold, Addidas. For IOC stod legenes værdi og prestige på spil. Uden det »Sovjetiske« hold ville legenes værdi være nedsat sportsligt og kommercielt. Det var Ukraine, der stædigt havde modsat sig denne løsning til de sidste. Ligesom med de baltiske lande viste historiens magt sig i denne situation. Rusland havde indtil 1914 haft sin Olympiske Kommitte, og var dermed den eneste af de nye stater, der kunne repræsenteres $\mathrm{i}$ manglen af en fælles løsning.

Ved OL i Albertville og Barcelona viste det Forenede Hold den fordums styrke ved at indtage den uofficielle førsteplads. Ovenikøbet fik det Forenede Hold det antal medajler, som den provisoriske ledelse i Moskva havde forudsagt. Elitesportens apparat havde været rystet, men viste sin professionalisme til det sidste.

Da sommerlegene var slut, tog atleter, trænere og ledere hver til sin stat. Det Forenede Hold var et intermezzo, der var slut.

\section{Rusland}

Rusland skulle nu opbygge sin egen idrætsorganisation, sin idrætspolitik osv. Det var en mere padoksal situation, end de fleste forestiller sig. Rusland havde på idrætsområdet som på så mange andre områder ikke haft sine egne strukturer. De enkelte republikker havde haft egne sportskommitter. Men ikke Rusland. Her gjalt umiddelbart Goskomsport. Men den centrale ledelse af Goskomsport havde jo ligget i Rusland og i Moskva. Hertil kom den specielle situation, at den tunge del af idrætsforskningen lå i Moskva og Skt. Petersborg, mens mange store idrætsanlæg lå i Republikkerne. I Tallin lå det olympiske sejlsportscentrum, i Medeo ved Almata i Kazakhstan lå det Olympiske skøjtecentrum. I Georgien lå det alpine centrum osv. Disse anlæg var Unionsanlæg. $\mathrm{Nu}$ var de ikke umiddelbart tilgængelige for Rusland, samtidig med at det var altfor store og kostbare i drift for Estland og de mindre nye stater

En ny idrætsmodel skulle bygges op i Rusland. Den økonomiske krise ramte nu hårdt overalt, også i idrætsverdenen. Hyperinflationdelen gjorde trænere til underbetalte specialister. Forskningsinstitutionerne kunne ikke lønne de ansatte. Det var dyrt at samle eliten, og ekstremt kostbart at sende folk til internationale konkurrencer. Børne- og ungsdomssportsskoler lukkede, og sendte deres børn til andre skoler eller ud i det civile liv uden et håb .

\section{Nye strukturer}

I to år siden Suvjetunionens opløsning havde Ruslands sportsmodel været genstand for improvisation. Den politiske magtkamp mellem præsident Jelzin og gammelkommunisterne i Folkekongressen havde også konsekvenser for sportspolitikken. Som på 
andre samfundsområder var reformarbejdet gået i stå som en følge af magtkampen. Naturligvis var sportspolitikken en mindre del af den uhyre omlægning fra en centralplanlagt partistat til een eller anden form for demokratisk styre og en markeds $\varnothing$ konomi. Der var kræfter blandt gammelkommunisterne i Folkekongressen, der var fortalere for en fortsættelse af den direkte statsstyring og statsfinanciering af idrætten. Jelzins fløj ønskede en større grad af uafhængighed for de sportslige organisationer, men også en form for statskontrol. I sportsorganisationernes ledelse og i sportsforskningsinstitutter blev der afholdt et utal af møder med henblik på at udstikke retningslinierne for den fremtidige sportsstruktur. Også her var der tale om en magtkamp om rektorposterne på uddannelsesinstitutionerne og lederposterne af forskningsinstitutterne. Sportens verden gennemspillede $\mathrm{i}$ miniatureformat den langstrakte revolution, der gjalt hele det russiske samfund.

I 1992 blev den Russiske Olympiske Kommitte etableret. Den skulle være uafhængig af staten og varetage den nationale og internationale elite. Sportens specialforbund skulle ligeledes være uafhængige af staten, og samarbejde på kontraktlig basis med ROC. Formanden for ROC blev V. Smirnov, der tidligere havde været formand for den Sovjetiske Olympiske Kommitte. Han var vicepræsident for IOC og havde spillet en hovedrolle i skabelsen af Det Forenede Hold til de Olympiske Lege i 1992. Som på så mange andre områder $\mathrm{i}$ Rusland blev der skabt nye strukturer, men de blev bemandet med medlemmer fra det gamle magtapparat, den gamle nomenklatura. Det $\varnothing$ konomiske grundlag for elitearbejdet blev indtægterne fra det Olympiske Lottospil »Million«, der var et onlinesystem med international kapital som en del af det økonomiske grundlag.
Den øvrige del af den nye idrætsstruktur var længere om at falde på plads. Et lovforslag fra marts 1993 skitserede en ny struktur, men forhandlingerne varede resten af året. Den øverste ledelse af idrætten skulle varetages af den Russiske Kommitte for Fysisk Kultur. Direkte under præsidenten er der en præsidentiel koordinationskommite. Denne struktur afspejler den stærke præsidentmagt, som blev vedtaget med folkeafstemningen om den ny forfatning i december 1993. I de enkelte republikker under den Russiske Føderation, i de store byer, på amts- og kommununeniveau dannes der sportskommitter, der lokalt har ansvaret for sportsaktiviteter og sportsanlæg. Et mindre antal breddeorganisationer (Urozhai for landbrug, Burevestnik for studenter etc) skal repræsentere breddesporten.

Essensen af denne model er en betydelig statslig styring. Staten skal gennem den Russiske Kommitte for Fysisk Kultur stadig fastsætte normer og regulativer for trænerkvalifikationer, præstationsnormer for den Fysiske Kultur, krav til sportsanlæg $\mathrm{mm}$. Den nye sportsmodel består i en blanding af statsregulering, kontraktregulering og kommerciel virksomhed. Således skal staten stadig financiere en del af den internationale elites træning op mod internationale konkurrencer. Hvor Goskomsport tidligere kunne diktere hele apparatet ned til den mindste detalje, lægger den ny model op til en kompliceret koordination mellem forskellige formelt uafhængige instanser med en stærk centralstyring. Problemerne i denne model er da også åbenbare. Hvordan koordinere indsatsen mellem de forskellige instanser og niveauer i denne blandingsmodel? Medens sådanne koordineringsproblemer er hverdagskost i vestens blandingssystemer, er det en helt ny situation for beslutningstagerne i Rusland, der alle er opdraget i den centralistiske sportsmodels tid. 
Endeligt er der i denne model ikke givet nogen større selvstændig plads til frivillige og uafhængige breddeorganisationer. Væg-ten ligger på stat, republikker og regionernes lokalstater. Denne model minder, ligesom den nye russiske forfatning, mest om den franske sportsmodel. I 1994 har det da også ført til en hektisk mødeaktivitet på alle niveauer for at få modellen til at fungere.

\section{Ideologien og filosofien}

I Sovjetperioden havde sportssystemet, som alle andre samfunds- og kulturområder, været underkastet Kommunistpartiets ideologi og den Marxistisk-leninistiske filosofi. I praksis indgik der imidlertid elementer fra den førrevolutionære russiske pæadagogik, og den sovjetiske sportsfilosofi blev aldrig kodificeret i konsekvente marxistiske termer, som det skete i 70.erne i DDR. Ideologien begrundede idrætten ved dens funktioner for sovjetsamfundet og for dannelsen af den socialistiske personlighed. Idrættens funktioner var at bidrage til opdragelsen af den socialistiske personlighed og til arbejde og forsvar. I 80.erne blev det almindeligt $\mathrm{i}$ forskerkredse at tale om idrættens funktion i skabelsen af en »kommunistisk livsmåde«.

Også før Gorbachevs reformprogram var der i sportsapparatet en bevægelse med nye legitimeringer af idrætten. Fra Goskomsports ledelse blev der udkastet forskningsprogrammer, der mere præcist skulle definere sportens og den fysiske kulturs begreber, herunder den fysiske opdragelse. Dette program begyndte i 1985 . Disse programmer fik til følge, at der udspandt sig en teoretisk diskussion af grundbegreberne i den Sovjetiske sportsfilosofi. »Sport « blev difineret som konkurrenceorienteret, regelstyret bevægelsesaktivitet i enkeltkropsaktiviteter og »sportlige lege«, altså holdsport.
Sporten blev inddelt i international elitesport og masseorienteret konkurrencesport. »Fysisk Kultur« blev defineret som ikkekonkurrenceorienteret masseaktiviteter som gymnastik. De sovjetiske sportssociologer udviste her en betydelig skarpsindighed. Men det nye bestod i, at nogle filosoffer og sociologer fremhævede individets betydning og nødvendigheden af en individuel tilgang. Denne betoning af individets fysiske kultur og den individuelle motivation var knyttet til en indirekte kritik af den hidtidige sportspolitik.

Som nævnt skete denne nyorintering før Gorbachevs reformprogram. Men med de større muligheder for kritik hen imod slutningen af 80.erne blev den ideologiske nyorientering stærkere. Flere filosoffer og sociologer orienterede sig mod en humanistisk sportsfilosofi, der betonede det enkelte individ. Dette skete med en åben kritik af den hidtidige funktionalistiske sportsopfattelse. Baggrunden var en ny tendens i den sovjetiske sociologi, »kulturologien«. Kulturologien var en kultursociologi, der nu åbent vedkendte sig sin inspiration fra vestlige Cultural Studies og fra vestlig kulturteori. Enkelte forfattere agrumenterede for $\mathrm{n} \varnothing \mathrm{d}-$ vendigheden af en humanistisk kropssociologi med basis en en kulturologi, der forholdt til til vestlige kulturanalalytikere som Foucault, Turner osv. De mest radikale fortalere for en ny sportsfilosofi var V. Stoljarov og I. Bychovskaja. Dette var i den sovjetiske situation umiddelbar før revolutionen ikke kun et akademisk anliggende. Stoljarov grundlagde sin egen sportsbevægelse Spart på dette filosofiske grundlag. Det var ligeledes sådanne tanker, der åbnede for en diskussion af handicapidræt, som hidtil havde været næsten totalt fraværende. Det blev også filosofien bag ved et forsøg på at lokalisere årsagerne til breddeidrættens fallit $\mathrm{i}$ Sovjetunionen (Vinogradov). 


\section{Eliten}

Med Sovjetunionens ophør og den kommunistiske ideologis død måtte eliteidrætten finde en ny legitimation. Denne legitimation kunne ikke længere findes i systemkonkurrencen på sportens område eller i elitens resultater som et bevis på Sovjetunionens overlegenhed. Den nye legitimation er nu, at eliteidrætten er et »fors $\emptyset$ gsområde « for den menneskelige organismes formåen under ekstreme forhold. Derfor er den nødvendig. Dette forsøgsområde omfatter elitekroppens fysiske, psykiske og sociale formåenhed under ekstreme belastninger.

De nye organisatoriske rammer er nævnt ovenfor. Det russiske befolkningsgrundlag udgør under halvdelen af Sovjetunionens befolkning. Hvis Rusland skal fastholde sin status blandt verdens bedste, selvom Rusland ikke umiddelbart kan regne med en førsteplads, er det planen at udbygge nogle af de forudsætninger, der skabte den Sovjetiske dominans. Det er således planen at udbygge B $\varnothing$ rne- og Ungdomssportskolerne i landdistrikterne. Indtil 1991 var der ca. 4000 af disse skoler. Den $\varnothing$ konomiske krise har ført til, at ca. 500 er lukket. Det var især Fagforeningernes skoler, der er lukket på grund af pengemangel. Det er planen at 20 $\%$ af en børneårgang i fremtiden skal optages på disse skoler. Som bekendt er det hovedsagelig dagskoler, der er specialiserede i een idrætsgren. Det ugentlige undervisningstid i den specielle idrætsgren er 15 timer. Dertil kommer 4 timers undervisning $\mathrm{i}$ andre idrætsgrene. Dertil kommer de almindelige skolefag. Disse skoler kan nu modtage penge for afgangselever, når de sælges til russiske og udenlandske klubber. Markedsøkonomien er trængt helt ind i skolesystemet.

Ca. 1000 af de bedste landstrænere og hjælpetrænere er rejst til udlandet. Lønnen som træner i Rusland hører til de laveste. Mange atleter trænes nu af deres fædre eller ægtemænd. En hemmeligstemplet liste over eliten og dens trænere omfattede $\mathrm{i}$ 1993 kun 2500 atleter. Når den var hemmeligt, skyldtes det det traditionelle hemmelighedskræmmeri, men også den forskelsbehandling, der resulterede af de nye vilkår.

Der er ingen i det nye sportssystem, der har sat spørgsmålstegn ved den helt nye situation, der er opstået i Rusland. Den nye sportsorganisation vil på delvist statsfinancieret basis uddanne en elite, hvor de allerbedste i de kommercielt attraktive idrætsgrene vil overgå til den vestlige kommercielle elitesport. De idrætsgrene, der er kommercielt uinteressante, vil få svære vilkår. Ruslands sportssystem vil være rekrutteringsgrundlag for den internationale kommercielle elitesport. Det lillebitte mindretal af russiske atleter, der driver det så vidt, vil høre til de russiske nyrige i et land, hvis lønninger for gennemsnitsbefolkningen hører til på niveau med Brasilien og Mexico. Det reorganiserede sportssystem i Rusland fastholdes på et niveau, der er ude af trit med de sociale og $\varnothing$ konomiske realiteter. Det fastholdes for Apparatets skyld, ikke for den brede russiske befolkning. Revolutionen af den Store Røde Maskine er ikke fuldført, ligesålidt som de øvrige revolutioner i Rusland.

\section{Handicapidraet}

Det mest åbenbare ændring, der er et resultat af revolutionen i Sovjetunionen, er anderkendelsen af idræt for handicappede. I 1992 udsendte præsident Jelzin et dekret, der skal skabe bedre sociale vilkår for den handicappede befolkning. Fra 1995 skal alle ny- og ombygninger af veje, offentlige bygninger og boliger have faciliteter for 
handicappede. Rusland har en meget betydelig population af handicappede. De officielle tal regner med ca. 15 millioner, det er $10 \%$ af befolkningen, men forskerne nævner 30 millioner som et mere realistisk tal. Det er en enormt demografisk og socialt problem, der hidtil har været fejet under gulvtæppet i Sovjetunionen. Hidtil har denne befolkningsgruppe været placeret $\mathrm{i}$ institutioner, der samlede den specikke gruppe: blinde $\mathrm{i}$ een instition osv. Ellers har de været anbragt $i$ lejligheder uden muligheder for fri bevægelighed. Kun halvdelen af dem, der har behov for kørestole, har een sådan. Der er i den offentlige transport ingen faciliteter. Tværtimod er fortovskanter osv. vanskelige at forcere. Årsagerne til dette høje tal er et stort antal arbejdsulykker, krigsinvalider fra II verdenskrig og nu fra Afganistankrigen, samt forureningsforårsagede handcaps, fødselstraumer ol. Den generelt lave sundhedstilstand er medvirkende til en stor spædbørnsdødelighed.

Idrætssystemet skal nu udvikle aktiviteter for denne befolkningsgruppe. Der skal skabes faciliteter i bogligområderne. I Moskva, Skt. Petersborg og Khabarovsk skal der etableres rehabilitationscentre. I planene for perioden indtil år $2000 \mathrm{er} \mathrm{der}$ afsat 70.000.000.000 rubler (1993 priser). Dette er ca. 60 millioner DKR. En begyndelse. Der er udviklet træningssystemer og programmer af det lille bitte antal forskere, der nu arbejder med dette problem. Men der mangler penge til at føre disse planer ud i livet. Revolutionen har ført til, at problemet erkendes. Der er tale om en ideologisk nyorientering på baggrund af den nye humanisme i mindre kredse.

\section{Breddeidrat}

Den skarpeste aanalyse af virkeligheden blev leveret i et notat, som var beregnet til internt brug i den Russiske Kommitte for Fysisk Kultur. Denne analyse overgik i sin skånselsløse afdækning endog analyser i enkelte sportsaviser. Kun i private diskussioner med forskere og funktionærer kunne man høre noget lignende. Notatet stammer fra efteråret 93. Ifølge notatet var virksomhederne ved helt at opgive sin financiering af breddeidrætten. Som bekendt var det $\mathrm{i}$ sovjetperioden virksomhederne og fagforeningerne, der betalte idrætsfaciliteter og instruktion for de ansatte. Det var ved begyndelsen af 94 kun de mest velkonsoliderede virksomheder, der stadig opfyldte sin sociale pligt. $\mathrm{Nu}$ var denne aktivitet kun en $\varnothing$ konomisk belastning for virksomhederne. Der var virksomheder, der lejede sine idrætsfaciliteter ud til private motions- og aerobiccentre, der så indrettede dem med spejle og udstyr og drev et kommercielt motionstilbud. Men kun de nyrige russere kunne tillade sig den luksus at betale høje priser for aerobicundervisning. Så mange af disse motionsinstitutter måtte lukke.

De forsøg, der var gjort på at indrette idrætsfaciliteter i forbindelse med boligområderne, var ifølge notatet, mislykkede. Det var naturligvis en naturlig model for fremtiden, efter at den sovjetiske model var ophørt. Men den dybere årsag til denne fiasko for idræt i boligområderne ligger utvivlsomt i de fortvivlende levevilkår. Med een trediedel af befolkningen under fattigdomsgrænsen, og een trediedel, der kun lige kunne klare sig, var der ikke i befolkningen noget overskud til idræt.

Tidligere i artiklen er det blevet nævnt, at det sovjetiske sportssystem havde tabt ungdommen $\mathrm{i}$ alderen fra 16 til 25 . Den havde etableret sig i en idrætsfjern ungdomskultur baseret på populære film og musik. Notatet gør opmærksom på, at idrætstilbuddene til ungdommen var en fiasko. Med opløsningen af kommunistparti- 
ets ungdomsorganisation Komsomol var ungdommen helt overladt til sig selv uden organiserede tilbud og uden mulighed for en fornuftig selvorganisering. Opløsningen af ideologi og normer i samfundet som helhed har skabt en disciplin- og indholdskrise i skolen. $\mathrm{Nu}$ var modsætningerne mellem den uofficielle ungdomskultur og kommunistpartiets ungdomspolitik forsvundet, men der var ingen alternativer og ingen midler til en ny ungdomspolitik og heller ikke til en ny sportspolitik for ungdommen.

\section{Folkelige lege}

I de forskellige minoritetsrepublikker i Rusland, og naturligvis i de nye selvstændige stater med en ikke-russisk kultur, havde nationale idrætter forsat med at eksistere. I Georgien var det traditionel kaukasisk brydning og forskellige rytterlege. Selvom de havde indgået i den sovjetiske retorik, var de reduceret til et folkloristisk islet ved visse lejligheder. Det var de moderne russiske idrætter, der blev fremmet fra Riga til Vladivostok. Efter sovjetunionens opløsning er der ingen ideologiske begrænsninger på genoplivelsen af traditionelle former for idrætter og lege. Opkomsten af traditionsbevidsthed og neonationalisme overalt $\mathrm{i}$ resterne af Sovjetimperiet kan være et motivation til at de får en renaissance. Men den politiske ustabilitet og de nationale konflikter $g ø r$ det vanskeligt at se, hvordan de nye stater kan støtte dem $\mathrm{i}$ større stil. I alle tilfælde vil de nye stater benytte den internationale sport til at vinde anerkendelse.

I Ruslands nationale republikker er der dog tegn på, at Burjaternes traditionelle brydeform vinder udbredelse. Ligeledes er de rytterlege, der udøves i et bredt bælte af det sydlige Rusland og af flere minoriteter, populære. Det gælder for tartare og kosakkulturen, der nu optræder med en stærk national og kulturel selvbevidsthed, der utvivlsomt vil føre til en genoplivelse af traditionelle idrætter i forbindelse med folkelige fester og helligdage.

I selve Rusland, dvs. i den slaviske befolkning, er der kun få traditionelle lege tilbage. Det er imidlertid interessant, at der er nu er en interesse $i$ at genoplive folkelige kampidrætter og selvforsvarsformer, der næsten var helt uddøde. Det er imidlertid tankevækkende, at konteksten for denne genopdagelse i nogle tilfælde er baseret på en ultranationalistisk ideologi, der har direkte fascistiske træk. Der er således i Rusland en organisation for genoptagelse af de slaviske kampsportsarter, der åbent forbinder disse idrætter med den ariske races overlegenhed og antisemitisme. Den udgiver et blad, der intressant nok har reklamer for vestligt sportstøj. Den revolutionære forandring skaber her som andre steder $i$ det Russiske samfund de særeste kulturelle og politiske alliancer meller det moderne, det traditionelle, og det antimoderne. Disse kampsporter udøves i traditionelle bondedragter.

\section{Perspektiver}

En revolutionær forandring, som den der på nogle planer er sket i det Sovjetiske Imperium, er en kærkommne leglighed for en historisk og sociologisk betragtning. I den Sovjetiske revolution giver det mulighed for at trænge dybere ned i det system, der var, og konfrontere myter og realitet på samtlige idrættens områder. Det er også muligt at studere opkomsten af nye idrætsformer, nye kontekster og nye kulturelle og politiske betydninger.

Tendenserne, der nu aftegner sig, kan sammenfattes på følgende måde. 
Der er en tendens til en statslig centralreguleret breddemodel. Det kommunistiske diskurs er her erstattet af en ny diskurs, men i de gamle former. Dannelsen af den kommmunistiske livsmåde er simpelt hen skiftet ud med »en sund livsmåde«. Den er baseret på en stadig livskraftig illusion om ledelse og agitation fra oven, som løsningen på fiaskoen. Det er den model og den diskurs, man finder $\mathrm{i}$ den Russiske Kommitte for Fysisk Kultur. Den største hindring for realiseringen af den nye breddemodel i Rusland er den sociale elendighed. I et komparativt perspektiv er det tankevækkende, at den Sovjetiske »masseidræt « spillede fallit, og at den nye russiske model fortsætter i det gamle spor. Breddeidrættens popularitet igennem de sidste årtier $\mathrm{i}$ vesten skyldes utvivlsomt, at idrætten gennem et utal at incitamenter er blevet attraktiv som en del af en rimelig stor del af befolkningens livsstil. Den er i vesten en del af mange forskellige livsstile, der understøttes af den generelle krops- og konsumkultur, der betoner individets kropslige fremtoning, som en del af det sociale selv. Alt det var fraværende i de kommunistiske systemer for masseidræt. Ideologien om idrættens funktioner for arbejde og forsvar tilhørte en »industrialiserings-modernisme«, der var dybt forældet.

Der er en ny elitemodel baset på statsregulering, et formelt uafhængigt ROC og uafhængige specialforbund. Denne model bygger på statsregulering, kommercialisme og kontraktforhold. Denne blanding er ny, og dens evne til at præstere resultater vil først vise sig i løbet af 4 til 6 år. Indtil da le- ver elitens resultater på kapitalen fra Sovjetsystemet.

Der er en humanistisk sportsfilosofi baseret på en kulturologi i meget små kredse. Der er også praktiske fors $\emptyset g$ på at virkeliggøre denne filosofi i en blanding af idræt på tværs af aldersgrupper og køn. De nye initiativer i idrætten i Rusland er baseret på en traditionel humanisme og idealisme.

Der aftegner sig en hovedstrøm i bredden og eliten. Det er i denne mainstream karakteristisk, at planlægningsformerne fortsætter i en form for statsregulering. Det er nye demokratiske former, men det er den gamle nomenklatura, der befolker de »nye « organisationer.

Revolutionen af det sovjetiske sportssystem viser med al tydelighed de komplekse sammenhænge mellem sportens eget system og samfundssystemet. Det sovjetiske samfund repræsenterede en ufuldendt modernisering, der ikke kunne moderniseres. Elitesportene var det subsystem, der kunne perfektioneres gennem denne form for planlagt halv-modernitet, så længe det varede. Sovjetsystemet formåede at skabe den Store Røde Maskine som verdens hidtil mest effektive maskine til at frembringe sportsresultater. Masseidrætten var en Potemkinkulisse, der mere mindede om det sovjetiske systems manglende evne til at skabe resultater på mange livsområder. Resterne af det Sovjetiske sportssystem er udgangspunktet for det nye Ruslands sportspolitik. Denne virkelighed i sporten og den fysiske kultur har nu i 1994 fået sine nye organer, ligesom det politiske liv har fået sin presidentielle forfatning. 